THURSDAY, MARCH 24, 1870

\section{THE TRANSITS OF VENUS IN I874 AND 1882}

A Parliamentary paper issued at the close of last session gives some information on what is intended to be done in the matter of the great approaching astronomical events of 1874 and 1882 , which will interest many readers of NATURE. The correspondence on this subject between the Astronomer Royal and the Hydrographer of the Admiralty, and between the Hydrographer and the Secretary to the Admiralty, is given at full length, and together with the appended remarks of Captain Toynbee, Admiral Ommaney, Commander Davis, Mr. Stone, and Mr. Warren De la Rue, well merits careful perusal. On the whole it seems to be at least doubtful whether the requisite Antarctic station for the observation of the transit, which in the opinion of the Astronomer Royal should, if possible, be in the neighbourhood of Mounts Erebus and Terror, can be attained, or if, when attained, it is likely to be possible to make observations from it. But this Antarctic station is only required for the transit of I882, and there is ample time to make a preparatory Antarctic expedition to ascertain the doubtful point. In the meantime, however, let us see what has been settled about the transit of 1874 . For the proper observation of this event the Astronomer Royal informs us that it will be necessary, after making allowance for all the aid that may be expected from foreign and colonial observatories, to organise expeditions to the following five stations:-(I) Oahu (Sandwich Islands), (2) Kerguelen's Island, (3) Rodriguez, (4) Auckland (New Zealand), (5) Alexandria. At the first three of these stations-namely Oahu, Kerguelen's Island, and Rodriguez-it will be necessary to make preparatory observations for twelve months, in order to ascertain the absolute longitudes of these places, which are not exactly known. The total cost of these proposed observing expeditions for the transit of 1874 is estimated by the Hydrographer at $10,404 l$, a sum which, it must be admitted, is moderate for work of such surpassing importance, and, as the Lords of the Treasury state that they have "no objection to offer" to the proposed expenditure, we may take it for granted it will be so far carried out. But what $I$ wish to call attention to at the present moment is the valuable opportunity thus offered for still further augmenting the importance of this event to the progress of science generally, by converting these proposed astronomical expeditions into expeditions for general scientific observation. At three of the spots to be visited it will be necessary to keep up an observing party, more or less extensive, for upwards of twelve months. Now, it so happens that the three spots thus selected for astronomical observatories are also of very great interest for biological studies. The Sandwich Islands are well known to be the seat of a most peculiar indigenous flora and fauna, which has been hitherto very incompletely explored, rivalling perhaps even that of the Galapagus in eccentricity. They are likewise the seat of some of the most stupendous volcanic phenomena known un the globe. Who can doubt that one or more zoologists, botanists, and geologists would find ample work cluring a twelvemonth's sojourn in these islands, and would reap a rich harvest of results? The little island of Rodriguez was formerly the residence of a bird allied to the Dodo, and probably of other extinct forms o life. Professor Newton and his brother have, it is true, already made us tolerably well acquainted with the osteology of Pezophaps, as this gigantic ground-pigeon is termed. But there is no doubt that a careful exploration of the bone-caves of Rodriguez will lead to still further discoveries as regards Pezophaps, and most probably result in bringing to light other unknown extinct inhabitants of the submerged continent, which was the ancient focus of Didine life. Kerguelen's Island, the third point selected for a temporary astronomical observatory, is also in many points worthy of renewed investigation, Although we may probably believe Dr. Hooker, who visited it during Sir James Ross's Antarctic Expedition, left but few plants for future botanists to discover, the seals and whales that frequent its shores, together with the sea-fowl and other inhabitants of the coast, would well occupy the attention of zoologists. It is, moreover, of especial importance that the "abundant fossil remains" of its now extinct forests should be thoroughly investigated, in order to obtain more knowIedge of the former distribution of land and water in the South Pacific. I have mentioned only some of the principal and most noticeable points for biological inquiry in each of these three localities. But, as every naturalist knows, in the case of such isolated land-areas as these marine islands, it is of especial importance to the progress of our knowledge of general geographical distribution to have a complete account of every branch of their faunas and floras, both recent and extinct. I beg leave, therefore, to urge upon all who are interested in the progress of science, the importance of not losing the opportunity that now presents itself. The additional expense of attaching two or three qualified Natural History observers (or at any rate collectors) to these three expeditions could not be very great. The numerous American and Russian exploring expeditions are invariably accompanied by zoological and botanical collectors, nor is the money required to publish the results obtained by them grudged by the Governments of these countries. Even povertystricken Austria did not send the Norlara round the world without a competent corps of naturalists, and we are now reaping the fruits of the abundant harvest which they gathered in. Far from lagging behind, wealthy England ought to take the lead in such cases, and instead of its being necessary, when an opportunity of the sort occurs, to take all kinds of extraordinary steps in order to induce the Government to take advantage of it, such things should be done as matters of course.

P. L. S.

\section{PHILOLOGY AND DARWINISM}

TThe following paper was written nearly half a year ago, before the translation into English of Prof. Schleicher's two pamphlets, by Dr. A. V. W. Bikhers. After reading the article on Dr. Bilkhers' translation, by Prof. Max Müller, in a previous number of NATURE, it struck me that many readers might be glad to have some further account of Schleicher's views. F. W. F.]

$T \mathrm{HE}$ relations of the science of language to the Darwinian hypothesis have been touched upon by one of the most acute and learned of modern scholars, 
Prof. August Schleicher, of Jena, whose lamented death a year ago, * at the early age of forty-eight, is a severe loss to European science, was an ardent supporter of the doctrine of variability of species. Besides being a most eminent linguist, he had long been interested in practical botany; and as a cultivator of ferns he had enjoyed many opportunities of observing the apparent transformation of natural subdivisions. It was not, however, as a botanist that Mr. Darwin's book was mainly interesting to him, but far more from the light which his theories seemed to throw on the phenomena of language. The first edition of the "Origin of Species" appeared in November 1859 , and Prof. Schleicher, three years before he had met with Brown's German translation of it, had in his book, "Die Deutsche Sprache" (pp. 43, 44), called attention to the struggle for existence among words, the disappearance of primitive forms, and the immense development and differentiation which may be produced by ordinary causes in a single family of speech. On receiving Mr. Darwin's book from his friend Prof. Häckel, he wrote him a letter, which has since been published, on "Die Darwinsche Theorie und die Sprachwissenschaft ;" and in answer to the objection that he had, in this letter, assumed that languages were material existences, having a real natural life, he wrote a second pamphlet on the "Importance of Language for the Natural History of Mankind."

The general line of illustration which he adopts had probably struck others, and it had certainly struck me before I read or heard of Prof. Schleicher's pamphlet; but as that little work is as yet but slightly known in England, it will probably be interesting to some readers if I sketch the outline of his arguments. There was nothing fanciful or precipitous in Schleicher's writings. He was one of the most strenuous supporters of the strictly scientific character of all true linguistic inquiry; one of the most severe opponents of those vague fancies, imaginative theories, hazardous etymologies, and $d \overrightarrow{\text { priori inferences }}$ which have thrown suspicion on philological work. He had owed much, even in the study of language, to such books as Schleiden's "Scientific Botany," and the "Physiological Letters" of Carl Vogt ; and he wished to found linguistic science on the structure of the organs of articulation and on recognised vital laws. He regarded languages as natural organisms which, in accordance with definite physical influences, and independently of human will, are produced and developed, grow old and die, and therefore manifest the series of phenomena to which we give the name of "life." Hence he regarded Comparative Philology, not as an historical, but as a natural science; and we think that his views will be shared by all who have added to their linguistic inquiries some sound knowledge of either zoology or botany.

The researches of Sir Charles Lyell have shown that the present condition of the earth's surface is due, not to cataclysms and conflagrations, but to the slow result of natural laws continuing to act during thousands of years. Similarly, Mr. Darwin showed that the existing conditions of species might have been originated by continuous insensible modifications, working for an indefinite period of time. It was the main object of Prof. Schleicher to show that in all essential particulars the working of similar laws accounted for the existing phenomena of languages. The

\footnotetext{
* He died on Dec. 6, r868.
}

principles of classification apply to language no less than to animal and vegetable organisms. A genus corresponds to a linguistic stem; classes to linguistic families ; subspecies to dialects; varieties to minor dialectic peculiarities; and, finally, individuals to those special modes of varying utterances which distinguish man from man.

Mr. Darwin has constructed an ingenious diagram* to illustrate the immense scope which must be allowed for gradual divergence of characters in animal and vegetable species derived by natural selection from an original genus. Schleicher has made an exactly similar table to serve as a genealogical tree for the Aryan Families of language. But here the philologist has a distinct advantage, and the study of his results may be most suggestive to the naturalist : for the Darwinian diagram is to a great extent ideal and.hypothetical; while the table of languages is merely an expression of indisputable discoveries. Any one who has clearly understood the certainty of the fact, that languages at first sight so different as Greek and French, Icelandic and Portuguese, Sanskrit and Lithuanian, are yet connected with each other by close bonds of union, and that the phenomena they exhibit are due to gradual differentiation from a single stock, will undoubtedly be more able to conceive the possibility of Newfoundlands, and Greyhounds; and King Charles's Spaniels, and Wolves being lineal representatives of a common type.

And further than this, the philologist has another very positive advantage over the naturalist. The ethnologist can not only prove, where the naturalist must be content to conjecture, but can also more easily exemplify the birth of new forms out of anterior ones, and can carry out his examination on a greater scale. There are some languages and families of languages which have been under close observation for two thousand years, and which furnish us with written specimens of forms which have undergone immense subsequent modification. In comparing modern French with the Latin of the XII. Tables, or Mahratti with the Sanskrit of the Vedas, we have a sure and solid basis of observation, in which, by the aid of records incapable of falsification, we can observe the corroding and modifying influence of time on human speech. The effects of foreign influences on different languages even furnish us with some analogy to crossing, which is so important an element in all zoological inquiries. In point of fact, the possession of written materials extending over many ages led philologists to be among the first to deny the sudden origin of separate species. The Science of Language offers the most demonstrable and instructive examples of the gradual growth of species from common primitive forms, although it is as impossible in language as it is in zoology to draw certain and definite lines of demarcation between genera, species, and varieties.

It may be asked whether the science of language is able at present to demonstrate the growth of all families from one primitive mother-tongue? The answer must be frankly in the negative, and perhaps one reason for this may lie in the fact that there is not any linguistic family except the Aryan, of which the archetypal forms have been reconstructed from their derivatives. $\dagger$ But, on the other hand, as regards the morphology of language, we are

* Origin of Species, p. I30. (4th edition.)

+ To effect this was the object of Prof. Schleicher's Compendium der Vergleichende Grammatik. 
perfectly in a position to show that the rudest forms $c_{f}$ the most developed language have sprung, by insensible derivation, from phonetic signs as vague, simple, and monosyllabic as those of Chinese itself. These signs left the mutual relations of ideas unexpressed. There were at first no special vocal expressions, no organs for the fulfilment of grammatical functions, or the interdistinction of nouns and verbs, much less of conjugation or declension. Such words as That, gethan, Thuer, Thäter, thätig, all foint back to a root $t^{\text {tha }}$, which contained in itself the undeveloped germ of all sorts of verbal, nominal, and advcrbial modifications. And in this respect the ultimate roots of the Aryan languages closely resemble in character the actual words of those languages which have remained to this day as nearly as possible in their primitive condition. Such roots may without fancy be called speech-cells, in which the rudiments of all special organs are implicitly involved, but in which they are as little developed as in the germinal vesicles which represent the earliest forms of animal and vegetable life. There may have been multitudes of such sound-cells, as it were, from which different families of language have sprung by special lines of development, just as, according to the Darwinian hypothesis, many primordial cells, presenting a close similarity, may have been the earliest rudiments of all living organisms.

In speaking of the extinction of species and the struggle for existence, Mr. Darwin uses language which may be literally applied-applied without even verbal modification-to the phenomena of languages. Here, no less than in the animal and vegetable kingdom, the dominant forms of the prevailing groups tend to leave many modified descendants, while the imperfection of the weaker groups leads to their gradual disappearance. But the complete extinction of a linguistic type is a slow process, and just as extinct animal forms may leave behind them a few decaying representatives in inaccessible or solitary places, so in the mountain-valleys of the Pyrenees and the Caucasus, we find isolated dialects which may be the fragmentary relics of tongues once spoken in immense districts. But a language once extinct, like an extinct species, can never under any circumstances reappear; and its place is occupied by the nearly related but greatly modified groups of predominant families, which are precisely those which undergo the completest differentiation in the course of their gradual victory over less happily constituted forms. And in consequence of the extinction of languages many intermediate forms have perished ; the primitive relationships of languages have been disturbed by all sorts of cxternal influences, and consequently languages radically different are now found existing side by side. All this, as every naturalist is well aware, represents a condition of things precisely similar to that which prevails in animated nature.

Mr. Darwin, in his great work, devotes a few words to the classification of languages as affording a confirmation of his theories. It does so to an extent of which probably he was not at first aware. In two capital points, viz., (I), the immense changes which can be effected by infinitesimally gradual modification; and (2) the preservation of the best and strongest form in the struggle for life, Mr. Darwin's hypothesis may be confirmed and verified by the entirely independent researches of the comparative philologist. These are the two points to which Prof. Schleicher wished to draw attention in the pamphlet which I have here epitomised. They do not indeed represent the whole of the linguistic facts which might be adduced on this side of the question, and they leave out of sight others which might be alleged with great force in favour of an opposite view. Some of these I have endeavoured to set forth elsewhere, * and possibly there may be some future opportunity of again bringing this subject before the reader. My present object was to make the views of Prof. Schleicher more widely known than they have yet become among English naturalists and scholars.

F. W. FARRAR.

\section{THE PRIVATE LIFE OF GALILEO}

The Private Life of Galileo. Compiled principally from his correspondence and that of his eldest daughter, Sister Maria Celeste, nun in the Franciscan convent of S. Matthew at Arcetri. 307 pp. (London: Macmillan and Co. 1870:)

THE numerous works which have appeared with Galileo for their theme may be divided into three classes. Firstly, those which relate more particularly to his persecution by the Church, the position and influence of the Sacred College in his day, and its attitude towards science. Secondly, those which treat of his scientific labours apart from himself, their nature and character, and their influence on the propagation of truth, the advancement of modern philosophy, and the downfall of Aristotelianism. Thirdly, those which diseuss his private life. The first and last of these are often blended, more or less, and of necessity, but we know too little of his scientific labours. M. Parechappe has well remarked, "Le savant s'est effacé dans le martyr." The works of Galileo, if much talked of, are certainly little read-_" Il Saggiatore" and the "Dialoghi" are even less read than the "De Augmentis Scientiarum" and the "Novum Organum;" while the "Principia" of Descartes occupies a position of notoriety midway, perhaps, between "Il Saggiatore" and the "Novum Organum," and we have a little difficulty in placing the writings of Hobbes. Yet it is undeniable that the works of these four men have produced a more profound and permanent influence upon human thought than any which preceded them. There is but one epoch in the history of the world to be compared with their epoch; it is that of Aristotle.

The work before us belongs-both to the first and third of the above divisions, it relates mainly to the private life of Galileo, and resembles Arduini's "Primogenita di Galileo Galilei," more than any other work on the subject. The account of the private life of Galileo, unlike many such accounts, does not give us much insight into the manners and customs and conditions of society at the time of which it treats, both because Galileo had so little real domestic life, and because the main correspondence which furnishes these private details took place between a nun (who of all persons can know least of the external world) and Galileo himself, and her letters to him have been preserved, while his answers to them have perished. Your great philoscpher as a rule is exceedingly

* See a paper on "The Growth and Development of Language" in the Cambridge Fourtal of Philology. 